\title{
Example Sentences in Bilingual School Dictionaries
}

Liezl Potgieter, Department Afrikaans and Dutch, University of Stellenbosch, Stellenbosch (liezlpotgieter@gmail.com)

\begin{abstract}
Dictionaries are written for a specific user group and the content and presentation must therefore be directed/aimed at that specific target group. In the past dictionaries were often compiled without the lexicographers really taking time and researching the intended users and their specific needs. School dictionaries especially were often compiled after very little or no attention being paid to the users and their needs. This article will look at the role of example sentences in dictionary articles, different types of example sentences as well as the criteria for example sentences in bilingual school dictionaries in order to ensure that the final product is natural, typical, informative, intelligible and of use to the user.
\end{abstract}

Keywords: SCHOOL DICTIONARY, USER, USER NEEDS, EXAMPLE SENTENCE, VOCABULARY, LEMMA, CITATION, CITATION EXAMPLE, COMPETENCE EXAMPLE

Opsomming: Voorbeeldsinne in tweetalige skoolwoordeboeke. Woordeboeke word saamgestel vir 'n spesifieke gebruikersgroep en die inhoud en aanbieding moet daarom op die spesifieke teikengroep gerig wees. In die verlede is woordeboeke dikwels saamgestel sonder dat die leksikograwe werklik tyd daaraan bestee het om navorsing te doen oor die beoogde gebruikers en hulle spesifieke behoeftes. Skoolwoordeboeke is veral saamgestel sonder dat daar veel of enige aandag aan die gebruikers en hulle behoeftes geskenk is. In hierdie artikel sal daar gekyk word na die rol van voorbeeldsinne in woordeboekinskrywings, verskillende tipes voorbeeldsinne sowel as die kriteria vir voorbeeldsinne in tweetalige skoolwoordeboeke om te verseker dat die eindproduk natuurlik, tipies, informatief, verstaanbaar en van nut is vir die gebruiker.

Sleutelwoorde: SKOOLWOORDEBOEK, GEBRUIKER, GEBRUIKERSBEHOEFTES, VOORBEELDSIN, WOORDESKAT, LEMMA, SITAAT, SITAATVOORBEELD, GEBRUIKSVOORBEELD

\section{Introduction}

Dictionaries are written for a specific user group and the content and presentation must therefore be directed/aimed at that specific target group. In the past dictionaries were often compiled without the lexicographers really taking time and researching the intended users and their specific needs. School dictionaries especially were often compiled after very little or no attention being paid to the users and their needs. Often a number of articles were extracted from an existing bilingual dictionary and then published as a school dictionary, when in reality the so-called school dictionary was nothing more than a condensed ver- 
sion of the more comprehensive bilingual dictionary. One such example is Bosman, Van der Merwe and Barnes' Tweetalige Skoolwoordeboek which, according to the introduction in the tenth edition is a "shortened version" of the wellknown Tweetalige Woordeboek by Bosman, Hiemstra and Van der Merwe.

These shortened versions published as school dictionaries seldom meet the needs of the target users and often are more of a hindrance than a help. One of the big shortcomings in several bilingual school dictionaries, including Tweetalige Skoolwoordeboek and its successor, Pharos Afrikaans-Engels Skoolwoordeboek published in 2004, is that they supply the user with little or no contextual guidance (for example, labels) and/or cotextual guidance (example sentences).

Luckily, during the last few years lexicographers have become more and more aware of the importance of the so-called user perspective - determining who the intended target user is and what his or her specific needs are with regard to the dictionary. According to Tarp (2005: 8) "all theoretical and practical lexicographic work should be based on the dictionary functions which represent the assistance provided by a dictionary — by means of its lexicographic data - to a specific type of user in solving the specific type of problems related to a specific type of user situation". Over and above this, pedagogical lexicography in South Africa has also gained momentum and during the past few years several vastly improved bilingual and hybrid school dictionaries with example sentences as part of the dictionary articles have been released. Examples of such dictionaries are listed in the table below, along with the age group of the learners (the intended target users) the dictionary is aimed at.

\begin{tabular}{|l|l|l|l|}
\hline \multicolumn{1}{|c|}{ Dictionary } & \multicolumn{1}{|c|}{ Publisher } & \multicolumn{1}{|c|}{$\begin{array}{l}\text { Year of } \\
\text { release }\end{array}$} & \multicolumn{1}{|c|}{ Age group } \\
\hline $\begin{array}{l}\text { Nuwe woordeboek sonder grense } \\
\text { [NWSG] }\end{array}$ & $\begin{array}{l}\text { Maskew Miller Long- } \\
\text { man }\end{array}$ & 2004 & Grade 4-6 \\
\hline $\begin{array}{l}\text { Bilingual Learner's Dictionary } \\
\text { [BLD] }\end{array}$ & Pharos Dictionaries & 1998 & - \\
\hline $\begin{array}{l}\text { Oxford English-Afrikaans School } \\
\text { Dictionary [OEASD] }\end{array}$ & $\begin{array}{l}\text { Oxford University } \\
\text { Press }\end{array}$ & 2007 & Grade 4-9 \\
\hline $\begin{array}{l}\text { Oxford English-Northern Sotho } \\
\text { School Dictionary [OENSD] }\end{array}$ & $\begin{array}{l}\text { Oxford University } \\
\text { Press }\end{array}$ & 2007 & Grade 4-9 \\
\hline $\begin{array}{l}\text { Oxford English-Zulu School Dic- } \\
\text { tionary [OEZSD] }\end{array}$ & $\begin{array}{l}\text { Oxford University } \\
\text { Press }\end{array}$ & 2010 & Grade 4-9 \\
\hline Grondslagfasewoordeboek [GSFW] & $\begin{array}{l}\text { Maskew Miller Long- } \\
\text { man }\end{array}$ & 2010 & Grade 1-3 \\
\hline
\end{tabular}

\section{The role of example sentences in dictionary articles ${ }^{1}$}

Example sentences play an important role in school dictionary articles and should supplement and possibly extend the definitions (Creamer 1987). Accord- 
ing to Creamer (1987: 241) an example can "take the burden off a definition by showing various ways the entry can be translated in context, indicate typical modifiers and illustrate points of usage". When specifically focusing on learner dictionaries one finds that examples in learner dictionaries are "intended to illustrate the meanings of words more clearly than is sometimes possible within the definition" (Herbst 1989: 1382). The role of example sentences in dictionary articles (especially in school dictionaries) should therefore not be underestimated.

\section{Different types of example sentences}

A distinction can be made between three different types of example sentences, namely citations, citation examples and competence examples (Bergenholtz and Tarp 1995: 139). Citations are quotes from recorded language usage (usually recorded in a corpus) and have been taken from authentic texts without subsequent adaptation by the lexicographer (Bergenholtz and Tarp 1995: 139). Although citations have the advantage that the user may always be certain that the example represents reality, the citations may also reflect slightly deviant usage (Bergenholtz and Tarp 1995: 139). Furthermore, even with a large corpus it may be difficult for lexicographers to find examples of the appropriate length, citations often aren't concise enough to be effective examples and it might not always be possible to find an apt example illustrating the specific usage of the lemma (Bergenholtz and Tarp 1995: 139; Gouws 1989: 228). In such cases lexicographers often make use of citation examples which are shortened or adapted citations from which names, meaningless adverbial phrases, data in brackets, et cetera are excluded. Although the adaptation of citation examples can take a lot of time, they are more accessible and user-friendly than citations and can also save a lot of space in the dictionary (Potgieter 2011: 124).

The last type of examples - competence examples - are thought up by the lexicographer and based on the lexicographer's own abilities. It can often take a lexicographer up to half an hour to find a suitable citation from the corpus, but it will take him or her only a few minutes to think up a competence example. Competence examples are usually commonly found in Language for General Purposes (LGP) dictionaries and school dictionaries. But competence examples do hold the danger that they can sometimes be very stereotypical and/or reflect the lexicographer's personal views. Lexicographers are therefore warned to stay away from stereotypes and try to leave their personal views/ opinions out of the examples ${ }^{2}$.

In the case of school dictionaries, the lexicographers are free to decide whether they want to make use of citations, citation examples or competence examples. They can also choose to use a combination of all three types of example sentences. The important thing is not the source of the example, but whether the example sentence fits the criteria as listed and discussed below. 


\section{Criteria for example sentences in school dictionaries}

When compiling a bilingual school dictionary the following criteria should be kept in mind when writing/choosing example sentences. The more criteria the example sentences meet, the better and more suited they will be for school dictionaries and the users of these dictionaries.

\subsection{The example sentences must fit into a context the users will under- stand}

It is important that the example sentences chosen by the lexicographer to illustrate the use of the lemma, should be used within a context that the dictionary user will know and understand. It is therefore important that the examples should fit into the learners' world. If the context or use of the word is too foreign or the example sentence is too complicated, it will end up being more of a hindrance than a help.

The following is an example of an example sentence that is too far removed from the learners' world and therefore too foreign for a learner to understand. Therefore it does not clarify the meaning or use of the lemma to the learner.

lemile - cultivated $\downarrow$ E be e le bona bomang ba ka tlago ba sekiša kgoši ge a lemile mašemo ao e lego a gagwe? Who could have prosecuted the chief when he cultivated his lands?

Article 1: "lemile" in OENSD

As can be seen, although the headword "lemile" (cultivated) is used in the example sentence, the sentence in itself really has nothing to do with the word "cultivated" and doesn't help the learner in understanding the word "cultivated". The following example sentence, taken from the OEZSD is much more successful in explaining and demonstrating the meaning and use of the word "cultivate": "They agreed that they would cultivate one type of crop."

A second example of an example sentence that doesn't help explaining the meaning and/or use of the lemma, is the following.

danger - kotsi - Ask questions to make sure that the learners understand the danger of lightning. Botšiša dipotšišo go kgonthišiša gore baithuti ba kwešiša kotsi ya legadima.

Article 2: "danger" in OENSD

The following two example sentences from BLD and NWSG are much better illustrations of the meaning and use of the word "danger" and will therefore be of much bigger help to the learners consulting the dictionary. "Mense wat te vinnig ry, is 'n gevaar op die pad./People who speed are a danger on the road." 
[from BLD] and "Die matrose op die sinkende skip is in groot gevaar [danger/ peril]." (The sailors on the sinking ship are in great danger) [from NWSG].

Other examples of example sentences that are of little or no help to learners in understanding the meaning or use of the lemma are the following:

black person ... Moswana; Mothomoso ... Remember, a black person speaks the truth when he says that one who plots against others is often his own victim. Fela elelwa gore Moswana o be a rerešitše ge a re, sekhukhuni se bonwa ke sebataladi.

Article 3: "black person" from OENSD

completion ... phethagatšo ... The municipality is trying very hard to achieve the completion of what they promised the community. Mmasepala o leka ka maatla go fihlelela phethagať̌o yeo ba e tshepišitšego setšhaba.

Article 4: "completion" from OENSD

\subsection{The example sentences must fit the learners' vocabulary}

The next important criterion that the lexicographer has to keep in mind when choosing and/or compiling example sentences is that the example sentences must fit the learners' vocabulary. Segler mentions that an oft-cited criterion for the usefulness of examples is that they are comprehensible to the learner. "The more vocabulary items used in the example are unfamiliar to the learner, the less likely it is that the example will be helpful to him" (sic) (Segler 2007: 20). Since the school dictionaries listed above are mainly aimed at language learners between grades 4 and 9, the vocabulary used in the example sentences should also fit the vocabulary used by that age group. According to Drysdale (1987: 213) examples are comprehensible if they use styles, registers and vocabulary that are "both idiomatic and intelligible at the students' level of comprehension". If the majority of the words used in the example sentences are not found in the learners' general or defining vocabulary, the learners won't understand the example sentence and once again it will be more of a hindrance than a help. Article 5 is an example of a sentence where some of the words used (see the highlighted text) do not form part of the learners' active vocabulary, are above the learners' comprehension and therefore unintelligible. As a result the example sentence can cause confusion instead of clarifying the lemma.

šeo ... there they are (close to you) ... Mehlala ya mainamatšo šeo letlakaleng la bobedi. There are the examples of deverbative nouns, on the second page.

Article 5: "šeo" from OENSD

By rewriting the sentence as follows "There are the examples of different types of fruit.", it would much better illustrate the lemma as the learners wouldn't then focus on the words they don't know or understand, but on the use of the lemma (underlined). 
It is also recommended that lexicographers not make use of unnecessarily difficult phrasing in cases where there are simpler ways available in which to phrase the sentence without it losing its meaning. Article 6 is a good example of a sentence where unnecessarily difficult phrasing was used (see highlighted text).

centimetre ... sentimetara ... The car came to a standstill 30 centimetres from the post. Koloi e ile ya ema disentimetara tše masometharo go tloga koteng.

Article 6: "centimetre" from OENSD

In this particular example the lexicographer could rather have used the word "stopped" instead of the phrase "came to a standstill". None of the meaning would have been lost, but the learners wouldn't have been confronted with an unnecessarily difficult phrase distracting their attention from the word represented by the lemma of which the usage is illustrated in the sentence.

\subsection{The word represented by the lemma should be the focus of the exam- ple sentence}

Another important criterion in the compilation/choosing of example sentences for school dictionaries is that the word represented by the lemma should be the focus of the example sentence. This implies that when the dictionary user reads the example sentence supplied he or she should immediately be able to see which word is the lemma discussed in that particular article. The following example sentence is a good example of a sentence where the word represented by the lemma isn't the focus of the sentence and if the specific word wasn't printed in bold the reader would have had no way of knowing which word in this particular sentence is the word the sentence is supposed to further explicate.

him ... 2 yena Our group made an appointment with the teacher to discuss our project with him. Ithimba lethu linqume isikhathi sokubonana nothisha ukuthi lixoxe naye ngeprojekthi yethu.

Article 7: "him" from OEZSD

Just from reading the sentence it is difficult to deduce if the lemma of the article is group, appointment, teacher, discuss, project or him. The following example sentences from OEASD provide much better examples of the use of the word "him":

him ... hom ... Do you know him? Ken jy hom? ... I gave him some food. Ek het hom kos gegee.

Article 8: "him" from OEASD 
The following article (article 9) is another example of a poor example sentence where it is difficult to deduce what the word is that the sentence is supposed to explicate while the one thereafter is a better example of a good example sentence for the word "bad".

mpe ... 1 bad ... Ke phošo go itefetša go dilo tše mpe tše batho ba go dirilego tšona. It is a mistake to avenge yourself as a result of bad things that people have done to you.

Article 9: "mpe" from OENSD

bad ... 1 sleg ... Ek het slegte nuus vir jou: 'n motor het jou hond omgery. I have bad news for you: a car has run over your dog.

Article 10: "bad" from BLD

\subsection{The example sentences must clearly illustrate the meaning of the word represented by the lemma}

The next important criterion to keep in mind, is that the example sentences should clearly illustrate the meaning of the word represented by the lemma and therefore not be vague or obscure.

As mentioned before, example sentences play an important role in school dictionaries helping to illustrate the meaning of words more clearly than is sometimes possible within the definition (Herbst 1989: 1382) and therefore their value should not be underestimated. It is therefore important that the word that is supposed to be illustrated in the example sentence should be the focal point of the example sentence and that the sentences shouldn't be too vague or obscure for the learner to be able to clearly see and understand the word represented by the lemma's meaning.

In article 11 the example sentence is vague and obscure and it is difficult to deduce the meaning of the word represented by the lemma from the example sentence whereas the example sentence in article 12 illustrates the meaning of the word "end" a lot better.

end ... noun ... mafelelo; bofelo; pheletšo ... If he sees you holding that dress like that, that will be the end of you. Ge a ka go bona o swere roko yeo bjalo, e tla ba mafelelo ka wena.

Article 11: "end" from OENSD

end ... noun ... einde ... They get paid at the end of the month. Hulle word aan die einde van die maand betaal.

Article 12: "end" from OEASD

It is also important that when making use of example sentences extracted from corpora the sentence shouldn't lose its illustrative value when removed from the context in which it was originally written. 
By ensuring that the word represented by the lemma is the focal point in the example sentence and that the sentence clearly illustrates the use of this word, the lexicographer ensures that the example sentences are of a much higher quality and are of much more use to the learners.

\subsection{The example sentences shouldn't be too long and drawn out}

Another important criterion when it comes to example sentences in school dictionaries is that the sentences shouldn't be too long and drawn out. By keeping the sentences short and to the point, it is much easier to clearly illustrate the meaning of the word and to keep the word represented by the lemma the focus of the example sentences.

It is often the case that when learners are confronted with long and drawn out sentences that these sentences are citations selected from a corpus. These sentences often are long because they provide "superfluous detail in the name of authenticity" (Cowie 1999: 137). Cowie (1999: 137) argues that stripping away this extralinguistic information may be even more helpful for production than a lengthy example. Jacobsen et al. (1991: 2788) observes that "often an authentic example can be abbreviated or paraphrased without losing any of its illustrative value". Zgusta (1971: 265) also writes that when making use of citations "probably the best thing to do is quote ... a reduced part of a passage in a text from which those parts that are inessential are omitted".

When looking at the following examples one can see that they are so long and drawn out that it is difficult to follow the sentence and be able to see which word's meaning is supposed to be illustrated.

thelela ... slip ... Go kwagala gore ba rile ge ba tshela ye nngwe ya dinoka tša moo moruti Merensky a thelela godimo ga leswika gomme a robega letsogo. It was said that when they crossed one of the rivers, Pastor Merensky slipped on a rock and broke his arm.

Article 13: "thelela" from OENSD

By shortening the sentence, the meaning and use of the lemma is illustrated much more clearly: Peter slipped on a rock and broke his arm.".

Here are some more examples.

son-in-law ... umkhwenyana ... Parents who love their daughters dearly would want to have a say about who marries them, about the son-in-law to be. Abazali abathanda amadodakazi abo kakhulu bangafuna ukuba nezwi kulabo ababashadayo, abazoba abakhwenyana babo.

Article 14: "son-in-law" from OEZSD

The following shorter example sentence would have been a better choice: "My daughter's husband is my son-in-law.". 
-khiqiza ... produce; manufacture ... Inkampani ekhiqiza izimpahla zikagesi iLG Electronics isisayine isivumelwano seminyaka emithathu sokuxhasa iBafana Bafana. The company that manufactures electrical equipment, LG Electronics, signed an agreement to sponsor Bafana Bafana for three years.

Article 15: "-khiqiza" from OEZSD

A better example would have been: "LG Electronics is a company that manufactures electrical equipment.".

\subsection{The example sentences should help the learners with text production}

Another important criterion is that the example sentences should help the learners with text production by showing users which words are typically used with the word represented by the lemma. One of the functions of example sentences is to show the headword "in action" and show points relating to the word represented by the lemma, for example collocations of verbs, use of articles, grammatical behaviour, phrases used to accompany nouns, et cetera. That way, the learners will know which words to use in conjunction with the word represented by the lemma. Here are a few examples:

ruk $^{1}$... while ... Die kos sal oor 'n rukkie reg wees. The food will be ready in a little while.

Article 16: "ruk1" from OEASD

promise ... ukwethembisa; ukuthembisa ... The athlete showed promise at an early age. Umgijimi ukhombisa ukwethembisa nje eseneminyaka emincane.

Article 17: "promise" from OEZSD

lecture ... thuto ... The professor gave an interesting lecture on South African English. Profesa o file thuto ya go kgahliša ka ga Seisimane sa ka Afrika-Borwa.

Article 18: "lecture" from OENSD

loop ... Hulle het in die loop van [during] die jaar hierheen getrek.

Article 19: "loop" from NWSG

\subsection{The example sentences should include names from different cultures and language groups}

Lastly it is recommended that in cases where people are featured in the example sentences, the lexicographers should ensure that both male and female names are used (about $50 \%$ of each) and that the names also originate from the different cultures and language groups relevant to the target users. Should lexicographers run out of names, it is recommended they invest in name books, for example The A-Z of Names (Isabell Gauche) or Call me by my name (Lindiwe 
Mtembu-Salter) or consult one or more of the many websites with names found on the internet. This will ensure that the final product is culturally and racially inclusive and no racial, language or cultural groups are left out.

\section{In closing}

The listed criteria are only a few of the things that contribute to creating natural, typical, informative and intelligible example sentences in school dictionaries. It is important that an example needs to be an utterance that the user of a dictionary is likely to hear spoken by speakers of a language, it should complement the definition and help the user understand it better and it should be intelligible (Hiles 2009: 26-27). At all times lexicographers should ensure that the example sentences they choose for school dictionaries should help the user in language learning and usage and not hinder his or her learning process.

\section{Endnotes}

1. In this article only example sentences will be looked at and not collocations and/or phrases.

2. For years there has been a debate as to which type of example - citation, citation example or competence examples - is the best. For more on this debate, see Prinsloo and Gouws 2000.

\section{Sources}

Bergenholtz, H. and S. Tarp (Eds.). 1995. Manual of Specialised Lexicography: The Preparation of Specialised Dictionaries. Amsterdam/Philadelphia: John Benjamins.

Bosman, D.B., I.W. van der Merwe and A.S.V. Barnes. 1998. Tweetalige Skoolwoordeboek. AfrikaansEngels/Engels-Afrikaans. Cape Town: Pharos Woordeboeke.

Bosman, D.B., I.W. van der Merwe and L.W. Hiemstra. 1994. Tweetalige Woordeboek/Bilingual Dictionary. Cape Town: Tafelberg.

Cowie, A. 1999. English Dictionaries for Foreign Learners: A History. Oxford: Oxford University Press/Clarendon Press.

Creamer, T. 1987. Beyond the Definition: Some Problems with Examples in Recent Chinese-English and English-Chinese Bilingual Dictionaries. Cowie, A.P. (Ed.). 1987. The Dictionary and the Language Learner. Papers from the EURALEX Seminar at the University of Leeds, 1-3 April 1985. Lexicographica. Series Maior 17. Tübingen: Max Niemeyer: 238-245.

Drysdale, P. 1987. The Role of Examples in a Learner's Dictionary. Cowie, A.P. (Ed.). 1987. The Dictionary and the Language Learner. Papers from the EURALEX Seminar at the University of Leeds, 13 April 1985. Lexicographica. Series Maior 17. Tübingen: Max Niemeyer: 213-223.

Du Plessis, M. 1998. Tweetalige aanleerderswoordeboek/Bilingual Learner's Dictionary. Cape Town: Pharos Woordeboeke.

Gauche, I. 2005. The A-Z of names. Discover the Promise your Name Holds. Cape Town: Struik Christian Books. 
Gouws, R., L. Potgieter en S. Burgess. 2010. Grondslagfasewoordeboek. Afrikaans/English. Cape Town: Maskew Miller Longman.

Gouws, R.H. 1989. Leksikografie. Cape Town: Academica.

Gouws, R.H., M. Stark and L. Gouws. 2004. Nuwe woordeboek sonder grense. Cape Town: Maskew Miller Longman.

Herbst, T. 1989. Dictionaries for Foreign Language Teaching: English. Hausmann, F.J. et al. (Eds.). 1989. Dictionaries: An International Encyclopedia of Lexicography. Handbooks of Linguistics and Communication Science. 5.2. Berlin: Walter de Gruyter: 1379-1385.

Hiles, L. 2009. Examples in South African School Dictionaries: From Theory to Practice. Unpublished M.Phil. Thesis. Stellenbosch: University of Stellenbosch.

Jacobsen, J., J. Manley, and V. Pedersen. 1991. Examples in the Bilingual Dictionary. Hausmann, F.J. et al. (Eds.). 1991. Dictionaries: An International Encyclopedia of Lexicography. Handbooks of Linguistics and Communication Science 5.3. Berlin: Walter de Gruyter: 2782-2789.

Kromhout, J. 2004. Pharos Skoolwoordeboek. Afrikaans-Engels/Engels-Afrikaans. Cape Town: Pharos.

Mtembu-Salter, L. 2001. Call me by my Name. More than 2000 Xhosa, Zulu, Swazi and Ndebele Names. Cape Town: Kwela Books.

Oxford Afrikaans-Engels/English-Afrikaans Skoolwoordeboek/School Dictionary. 2007. Cape Town: Oxford University Press.

Oxford IsiZulu-InsiNgisi/English-Zulu Isichazamazwi Sesikole/School Dictionary. 2010. Cape Town: Oxford University Press.

Oxford Sesotho sa Leboa-Seisimane/English-Northern Sotho Pukuntšu ya Sekolo/School Dictionary. 2008. Cape Town: Oxford University Press.

Potgieter, L. 2011. Die ontwerp van vertalende vakwoordeboeke met vertalers as teikengebruikers: 'n teoretiese model. Unpublished Doctoral Dissertation. Stellenbosch: University of Stellenbosch.

Prinsloo, D.J. and R.H. Gouws. 2000. The Use of Examples in Polyfunctional Dictionaries. Lexikos 10: $138-156$.

Segler, T.M. 2007. Investigating the Selection of Example Sentences for Unknown Target Words in ICALL Reading Texts for L2 German. Doctoral Dissertation. Edinburgh: University of Edinburgh. [Online]. Available at: http://www.era.lib.ed.ac.uk/bitstream/1842/1750/3/Segler\%2520TM\%2520thesis\%252007.pdf [2011, 8 February].

Tarp, Sven. 2005. The Pedagogical Dimension of the Well-conceived Specialised Dictionary. Ibérica. Journal of the European Association of Languages for Specific Purposes 10: 7-21.

Zgusta, Ladislav. 1971. Manual of Lexicography. The Hague: Mouton. 